Transactions of the American Fisheries Society, 2000, v129, n2, p504-513. http://afs.allenpress.com/perlserv/?request=get-archive\&ct=1 ISSN: 0002-8487

DOI: 10.1577/1548-8659(2000)129<0504:FSSOLB>2.0.CO;2

(C) Copyright by the American Fisheries Society 2000 


\title{
First-Summer Survival of Largemouth Bass Cohorts: Is Early Spawning Really Best?
}

\author{
William E. Pine III, ${ }^{* 1}$ Stuart A. Ludsin, ${ }^{2}$ and Dennis R. DeVries \\ Department of Fisheries and Allied Aquacultures, Auburn University, Auburn, Alabama 36849, USA
}

\begin{abstract}
Previous work has demonstrated that survival of largemouth bass Micropterus salmoides through the first year of life can be size dependent, favoring larger individuals. Because size, diet biomass, lipid accumulation, and ultimately overwinter survival of juveniles are typically positively related to age, early spawning is clearly advantageous. However, a true understanding of which largemouth bass cohorts contribute to the new year-class remains somewhat unclear because these conclusions have largely been based upon fish collected during summer rather than fish collected during spring. Conceivably, even earlier hatched cohorts of largemouth bass could have existed in many of these studies, and these fish may simply not have survived to the summer collection period. In order to assess this possibility, we quantified first-summer survival of largemouth bass cohorts collected during 1992 and 1993 in Auburn, Alabama, ponds (which were $2-5$ ha each). Our results indicate that it is early-hatched cohorts that likely contribute to the new year-class. Although we found that early-hatched cohorts were lost between May and July, these losses were not attributable to age-dependent mortality; instead, sampling biases associated with avoidance of seines by older, larger young-of-year largemouth bass appear to have driven these shifts. In addition, because we found that size-dependent cannibalism during summer acted to remove smaller, later-hatched largemouth bass, early hatching may enhance survival during larval and early juvenile stages in southern systems (and not just during the winter period). Given this information, fishery managers may potentially be able to implement harvest regulations that are designed to protect large, early-spawning adults, thereby increasing the probability of producing a strong year-class by enhancing first-summer growth and, ultimately, recruitment to adult stages.
\end{abstract}

Predicting year-class strength and eventual recruitment to the fishery remains an elusive goal in fisheries management. Subtle variation in growth or mortality during larval and juvenile stages can significantly influence fish recruitment (Houde 1987, 1989; Rice et al. 1987). Factors such as sizeselective predation (Post and Evans 1989; Miranda and Hubbard 1994b) and size-dependent starvation (Miller et al. 1988), as well as abiotic factors such as water temperature (Kramer and Smith 1962; Rutherford and Houde 1995) and water level fluctuations (Mcdonough and Buchanan 1991), can all influence growth and survival of young-of-year fishes. Because mortality is typically greatest during early life stages in fishes (Hjort 1914; Houde 1989, 1994; Rutherford and Houde 1995), understanding the factors that affect growth and survival of larvae and juveniles is critical to our ability to forecast recruitment success.

\footnotetext{
* Corresponding author: wep@gav.ifas.ufl.edu

${ }^{1}$ Present address: Department of Fisheries and Aquatic Sciences, University of Florida, 7922 NW 71st Street, Gainesville, Florida 32653-3071, USA.

2 Present address: Department of Evolution, Ecology, and Organismal Biology, Aquatic Ecology Laboratory, The Ohio State University, Columbus, Ohio 43212, USA.

Received November 11, 1998; accepted June 22, 1999
}

A great deal of research has been devoted to understanding the recruitment mechanisms of largemouth bass Micropterus salmoides. As with other freshwater and marine fishes, growth and survival during largemouth bass early life stages appear to be critical in determining year-class strength and eventual recruitment into the fishery (Swingle and Swingle 1967; May 1974; Houde 1987, 1989; Townsend 1989; Mitzner 1991). Ludsin and DeVries (1997) demonstrated that largemouth bass navigate a series of interdependent critical events during their first year of life, events that ultimately control survival and year-class strength. They identified the switch from feeding on invertebrates to piscivory as a critical early life event that regulates summer growth, fall lipid accumulation, and survival during their first winter. Early-hatched largemouth bass cohorts consisting of larger fish were more successful in exploiting available fish prey than were their smaller, laterhatched counterparts during summer. As such, early-hatched fish in Ludsin and DeVries's study were able to maintain a length advantage over later-hatched fish, which resulted in enhanced fall lipid accumulation and reduced overwinter mortality of early-hatched fish (Ludsin and DeVries 1997). Prior work with largemouth bass (e.g., Keast and Eadie 1985; Miranda and Hubbard 
1994a; Phillips et al. 1995) as well as with bluegill Lepomis macrochirus (Cargnelli and Gross 1996) provides additional support for several of these conclusions.

Other work, however, has demonstrated that growth and survival of early-hatched individuals can sometimes be lower than that of late-hatched fish because of stochastic abiotic factors during larval and juvenile life stages (e.g., water temperature, discharge; Kramer and Smith 1962; Crecco and Savoy 1985; Rice et al. 1987; Mooij et al. 1994). Rutherford and Houde (1995) found that late-hatched striped bass Morone saxatilis exhibited higher growth and survival than did earlyhatched fish because of the more stable weather patterns and better growing conditions experienced by late-hatched larvae (relative to earlyhatched larvae).

Although Ludsin and DeVries (1997) demonstrated that hatch date was important to future recruitment success, their understanding was based upon fish collected during early July (i.e., juveniles). As such, the potential remains that fish could have been spawned even earlier than their early-hatched fish and these fish may simply not have survived to their July sampling period. If this had occurred, then fish with intermediate hatch dates would actually have recruited to the new year-class, a conclusion that is drastically different from the current thinking with regard to largemouth bass. In order to better understand the relationship between hatch date and year-class strength, we examined summer survival of largemouth bass cohorts collected during May through July (1992 and 1993) in Auburn, Alabama. With knowledge of whether early-hatched individuals were at a disadvantage relative to intermediate-hatched individuals during summer, resource managers could potentially begin to increase the probability of producing strong yearclasses of largemouth bass via reduced exploitation of large, early-spawning adults, thus advancing the average time of spawning in a population and possibly enhancing first-summer growth and survival of young-of-year largemouth bass (sensu Goodgame and Miranda 1993; Garvey and Stein 1998; Mion et al. 1998).

\section{Methods}

Study site.-Six ponds (2-5 ha; mean depth, 2-3 $\mathrm{m})$ located in Lee County in east central Alabama, were drained, and remaining water was treated with rotenone to eliminate existing fishes. Ponds were filled and stocked with age-1 lepomid sunfish (mostly bluegill, 2,500 fish/ha) during winter 1990-1991. Young-of-year largemouth bass (250 fish/ha) were stocked in June 1991. Fingerling grass carp Ctenopharyngodon idellus also were added in spring 1991 (12 fish/ha) to control aquatic macrophytes. Ponds were monitored during 1992 as largemouth bass-bluegill systems. Adult gizzard shad Dorosoma cepedianum (77 fish/ha) were added during February 1993 to assess the impact of young-of-year gizzard shad populations on largemouth bass-bluegill systems. However, because gizzard shad survived to juvenile stages only in one pond and because none of these young-of-year shad were available as forage to young-of-year largemouth bass because of gape limitations (Ludsin 1994), the influence of gizzard shad on these populations will not be considered here.

Collection and otolith procedures.-Young-ofyear largemouth bass used for otolith analyses were collected on 7 May, 21 May, 18 June, and 17 July during 1992 and on 28 May and 1 July during 1993; these largemouth bass were collected via seining $(4.5 \times 1.0 \mathrm{~m} ; 3-\mathrm{mm}$ mesh seine; $N=$ three fixed, 5-m shoreline sites per pond), and on 8-9 July 1993, largemouth bass were collected via boat-mounted DC-pulsed electrofishing. We collected fish with electrofishing gear during the second year because we were concerned that larger fish might be avoiding the seine, thus biasing our seine collections toward smaller individuals (Jackson and Noble 1995; Hayes et al. 1996; Garvey and Stein 1998). All fish were preserved in $95 \%$ $\mathrm{EtOH}$ for later laboratory analyses. In the laboratory, fish were measured [to the nearest $1.0 \mathrm{~mm}$ total length (TL)] and their otoliths prepared (following Miller and Storck 1982). Except for youngof-year largemouth bass collected on 8-9 July 1993, we selected subsamples of 20 fish per date per pond for otolith analyses, such that the lengthfrequency distribution of each subsample matched the length-frequency distribution of all seine samples in that pond on that date. Uneven sample sizes across sample dates were attributable to variable catches of largemouth bass across ponds. For fish collected on 8-9 July 1993, a subsample of 60 fish per pond was selected for otolith analyses in a similar fashion (see Ludsin and DeVries 1997). Otolith ring counts for all fish followed the methods of Ludsin and DeVries (1997). We used swimup dates to represent hatch dates, because daily growth rings from the yolk sac larval stage (i.e., pre-swim-up) are not distinguishable from one another (Miller and Storck 1982, 1984). Within years, we compared mean swim-up dates using 
one-way analysis of variance (ANOVA), and we compared swim-up-date distributions using Kolmogorov-Smirnov tests (SAS Institute 1985). Significance levels for all tests were set at $\alpha=0.05$.

Adult largemouth bass ( $>150 \mathrm{~mm}$ TL) were sampled with pulsed-DC electrofishing every 2-3 weeks during the study to quantify cannibalism. After measuring (nearest $1 \mathrm{~mm}$ TL) and weighing (nearest $1 \mathrm{~g}$ wet weight) collected adults, stomach contents were removed using clear Plexiglas tubes (Van Den Avyle and Roussel 1980). In order to assess whether cannibalism was size selective during summer, we used one-tailed $t$-tests and Kolmogorov-Smirnov tests to compare length distributions of young-of-year largemouth bass found in adult stomachs with length estimates of youngof-year largemouth bass collected in ponds. During 1992, length distributions of largemouth bass found in stomachs were compared with fish collected in seines within the same week. Because we were again concerned that seine samples may not be adequately capturing larger fish, for 1993 comparisons, we back-calculated largemouth bass length distributions during summer (i.e., 14 May, 28 May, and 25 June) using otolith ring-width measurements of fish collected (via electrofishing) on 8-9 July 1993. The potential for gear bias was further quantified by comparing seine samples from 1 July with electrofishing samples from 8-9 July (see Results and Discussion) using a $Z$ test (Zar 1984). For fish that were less than 5 weeks of age at the time of collection on 8-9 July, we relied strictly on otolith ring-width measurements to estimate size on earlier dates (quantified by Ludsin 1994; Ludsin and DeVries 1997). For fish that were greater than 5 weeks of age, we calculated an average daily growth rate (DGR) across all young-of-year largemouth bass collected on 8-9 July 1993, using the following equation:

$$
\text { DGR }=\left(\mathrm{TL}_{c}-6\right) / \text { age },
$$

where $\mathrm{TL}_{c}$ is the total length of fish at capture, age is the number of days since swim-up (as calculated by otolith ring count), and $6 \mathrm{~mm}$ is subtracted to correct for growth occurring prior to swim-up (Goodgame and Miranda 1993). In order to determine largemouth bass length on 25 June, we then subtracted this average DGR $(0.67 \mathrm{~mm} / \mathrm{d})$ for every day (i.e., 13-14 d) the fish was alive after 25 June. In order to estimate lengths on 14 and 28 May, we added the average DGR (when necessary) to our estimates of size at 5 weeks of age. Because the DGR was determined by averaging across the entire growth period of fish (including the slow growth period during larval stages; Ludsin 1994; Ludsin and DeVries 1997), our estimates of fish lengths in the ponds on 14 and 28 May are conservative (i.e., they likely underestimate true size).

\section{Results and Discussion}

Mean largemouth bass swim-up dates differed across collection dates during both years. During 1992, mean swim-up dates changed (one-way ANOVA: $F=134, \mathrm{df}_{3,416}, P=0.0001$ ) from early April for fish collected during early and late May (Figure 1a, b) to late April in June and July samples (Figure 1c, d), which indicated a loss of earlyhatched largemouth bass from our later collections. We observed a similar shift in mean swimup date (from 8 April to 10 May) for fish collected via seining from 28 May to 1 July 1993 (one-way ANOVA: $F=250, \mathrm{df}_{2,498}, P<0.0001$; Figure 1e, f); however, the mean swim-up date of fish collected via electrofishing on 8-9 July 1993 was similar (11 April; Figure 1g) to that for fish collected on 28 May. Because electrofishing is more efficient at capturing larger fish (including largemouth bass) than are seines (Jackson and Noble 1995; Reynolds 1996; Garvey and Stein 1998), these results suggest (1) that little age-dependent mortality occurred during summer 1993 (i.e., the 1 July seine sample may have been biased toward collecting smaller, late-hatched largemouth bass) and (2) that differences in mean swim-up date during 1992 also may have been an artifact of gear selection. Below, we attempt to delineate whether age-dependent mortality or sampling bias drove these changes in hatch-date distributions by examining adult diet data (to quantify the potential for size-dependent cannibalism) as well as by comparing total length and hatch-date distributions of fish collected via seining versus electrofishing.

The potential for cannibalism to be an important force in structuring young-of-year largemouth bass populations has been demonstrated (Kramer and Smith 1962; DeAngelis et al. 1980; Miranda and Hubbard 1994b). In these studies, cannibalism acted in a size-dependent manner, with predation selectively removing smaller individuals. Likely this occurs because smaller individuals are more vulnerable to a wider size range of predators (Post and Evans 1989) and are poorer swimmers than are larger individuals (Miller et al. 1988). Because we found that largemouth bass age and length were positively related during both years in our systems (Figure 2), for cannibalism to have been responsible for the observed differences in swim-up-date 

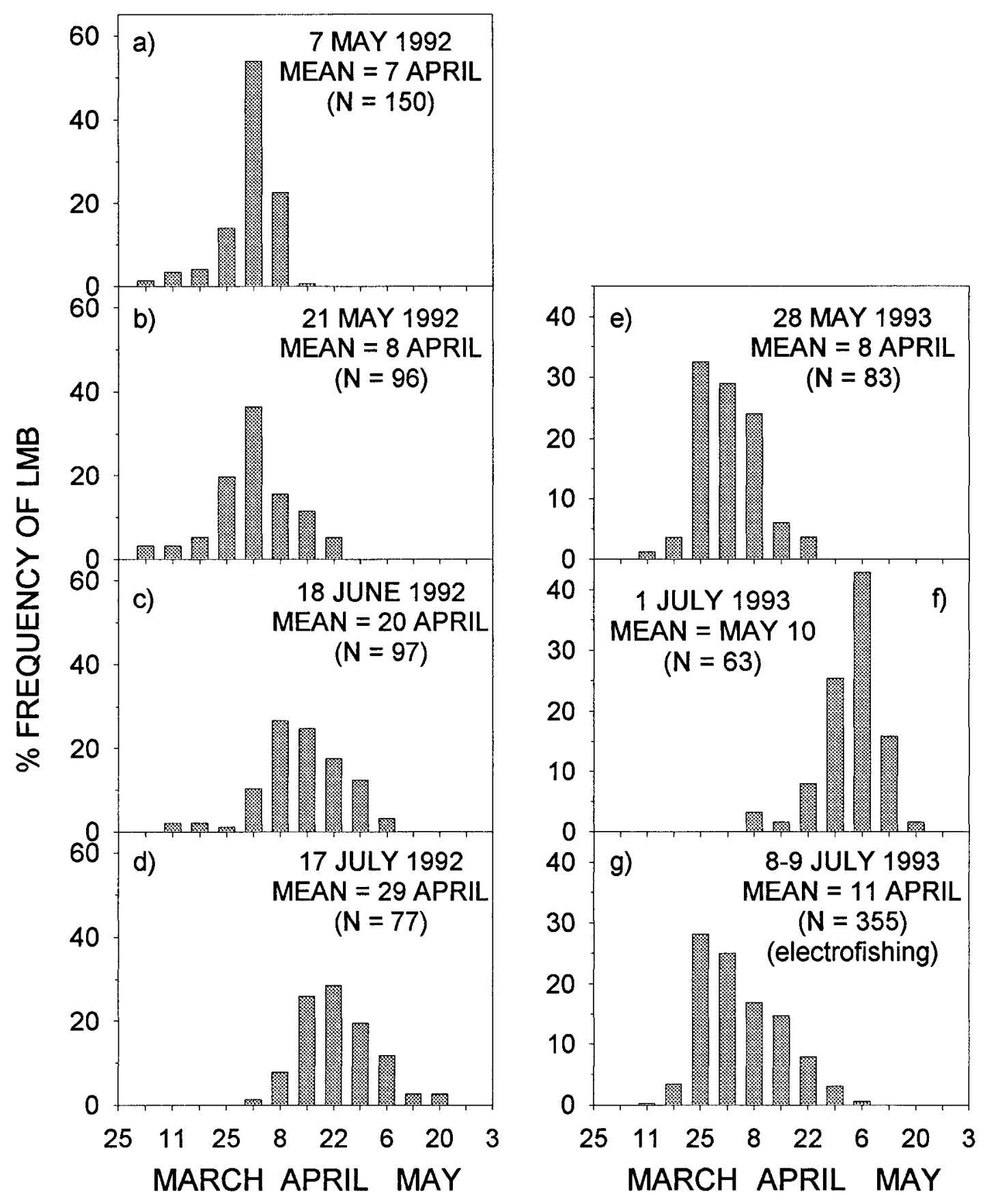

SWIMUP DATE

Figure 1.-Frequency distributions of 7-d-old swim-up cohorts for young-of-year largemouth bass collected on four dates in 1992 (left panels) and three dates in 1993 (right panels). The mean swim-up dates and sample sizes $(N)$ are included in each panel. Samples for panels a-f were collected via seining, whereas those for panel $g$ were collected via electrofishing. 


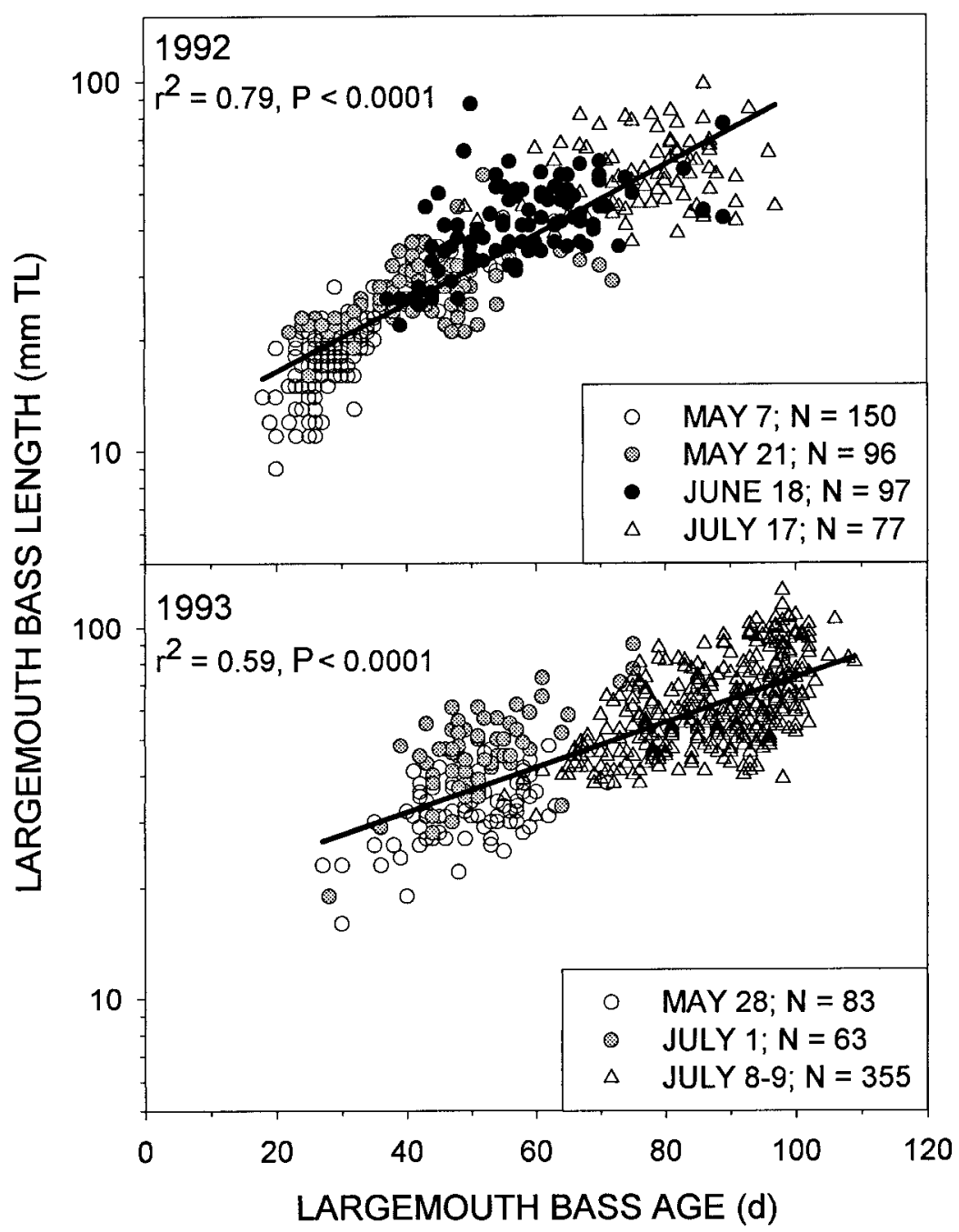

Figure 2.- Regression of fish length as a function of age for young-of-year largemouth bass collected during 1992 (top panel) and 1993 (bottom panel).

distributions across collection dates within years, it would have had to act to remove the larger, older individuals (i.e., opposite to the trends observed in previous studies). However, by comparing length distributions of largemouth bass cannibalized versus those of largemouth bass collected via seining (i.e., all 1992 comparisons) or versus those estimated by back-calculating length at age (i.e., all 1993 comparisons), we found that small (i.e., late-hatched; Figure 2) largemouth bass were more common in adult diets than were large fish (Table 1; Figure 3). Across all dates (except 26-29 June 1992), we found that mean largemouth bass lengths in adult stomachs were less than mean lengths of young-of-year largemouth bass in ponds. In addition, we found that lengthfrequency distributions differed between cannibalized and available (i.e., in the ponds) youngof-year largemouth bass, which indicated that sizeselective predation operated to remove the smaller, early-hatched fish (Table 1; Figure 3). As such, we conclude that cannibalism could not be responsible for the absence of early-hatched cohorts in June/ July seine samples.

Alternatively, the absence of large, early-hatched individuals in June/July seine collections during 1992 (and on 1 July 1993) was likely attributable to avoidance of the seine by larger individuals. Indeed, Garvey and Stein (1998) noted reduced capture efficiency of young-of-year largemouth 
TABLE 1.-Results of one-tailed $t$-tests and Kolmogorov-Smirnov grouped distribution tests used to compare mean total lengths (TL) and length distributions, respectively, of young-of-year largemouth bass (LMB) found in adult diets to those of young-of-year LMB captured in ponds. During 1992, LMB lengths in ponds were estimated from seine collections, whereas 1993 length-at-age estimates were back-calculated from daily otolith increments from fish collected via electrofishing on 8-9 July.

\begin{tabular}{|c|c|c|c|c|c|c|c|c|c|c|}
\hline \multirow[b]{3}{*}{ Date } & \multirow{3}{*}{$\begin{array}{l}\text { Number } \\
\text { of adults } \\
\text { sampled } \\
\text { (\% empty } \\
\text { stomachs) }\end{array}$} & \multicolumn{2}{|c|}{$\mathrm{TL}(\mathrm{mm}$, mean $\pm \mathrm{SE})$ of $\mathrm{LMB}$} & \multirow{2}{*}{\multicolumn{3}{|c|}{$t$-test statistics }} & \multirow{2}{*}{\multicolumn{4}{|c|}{ Kolmogov-Smirnov statistics }} \\
\hline & & \multirow{2}{*}{$\begin{array}{l}\text { In diets } \\
(N)\end{array}$} & \multirow{2}{*}{$\begin{array}{l}\text { In ponds } \\
(N)\end{array}$} & & & & & & & \\
\hline & & & & df & $t$ & $P$ & $D$ & $k$ & df & $P$ \\
\hline 5-9 Jun, 1992 & $\begin{array}{c}92 \\
(30.4 \%)\end{array}$ & $\begin{array}{c}35.3 \pm 1.5 \\
(13)\end{array}$ & $\begin{array}{c}39.3 \pm 0.4 \\
(404)\end{array}$ & 14 & -2.50 & 0.0100 & 89 & 11 & 403 & $<0.001$ \\
\hline 26-29 Jun, 1992 & $\begin{array}{c}108 \\
(22.2 \%)\end{array}$ & $\begin{array}{c}51.5 \pm 3.3 \\
(18)\end{array}$ & $\begin{array}{c}52.7 \pm 0.8 \\
(298)\end{array}$ & 314 & -0.33 & 0.3700 & 27 & 17 & 297 & $<0.001$ \\
\hline 9-16 Jul, 1992 & $\begin{array}{c}89 \\
(19.1 \%)\end{array}$ & $\begin{array}{c}51.4 \pm 2.2 \\
(22)\end{array}$ & $\begin{array}{c}57.9 \pm 1.1 \\
(162)\end{array}$ & 33 & -2.64 & 0.0060 & 42 & 18 & 161 & $<0.001$ \\
\hline 14 May 1993 & $\begin{array}{c}156 \\
(46.8 \%)\end{array}$ & $\begin{array}{c}22.2 \pm 0.7 \\
(116)\end{array}$ & $\begin{array}{c}38.7 \pm 0.6 \\
(352)\end{array}$ & 306 & -17.65 & 0.0000 & 205 & 11 & 351 & $<0.001$ \\
\hline 3 Jun, 1993 & $\begin{array}{r}25 \\
(36 \%)\end{array}$ & $\begin{array}{c}32.0 \pm 2.5 \\
(6)\end{array}$ & $\begin{array}{c}53.9 \pm 0.7 \\
(352)\end{array}$ & 105 & -10.21 & 0.0000 & 249 & 11 & 351 & $<0.001$ \\
\hline 25 Jun, 1993 & $\begin{array}{c}117 \\
(27.4 \%)\end{array}$ & $\begin{array}{c}39.7 \pm 1.2 \\
(41)\end{array}$ & $\begin{array}{l}55.0 \pm 1.0 \\
(355)\end{array}$ & 6 & -8.44 & 0.0001 & 118 & 20 & 354 & $<0.001$ \\
\hline
\end{tabular}
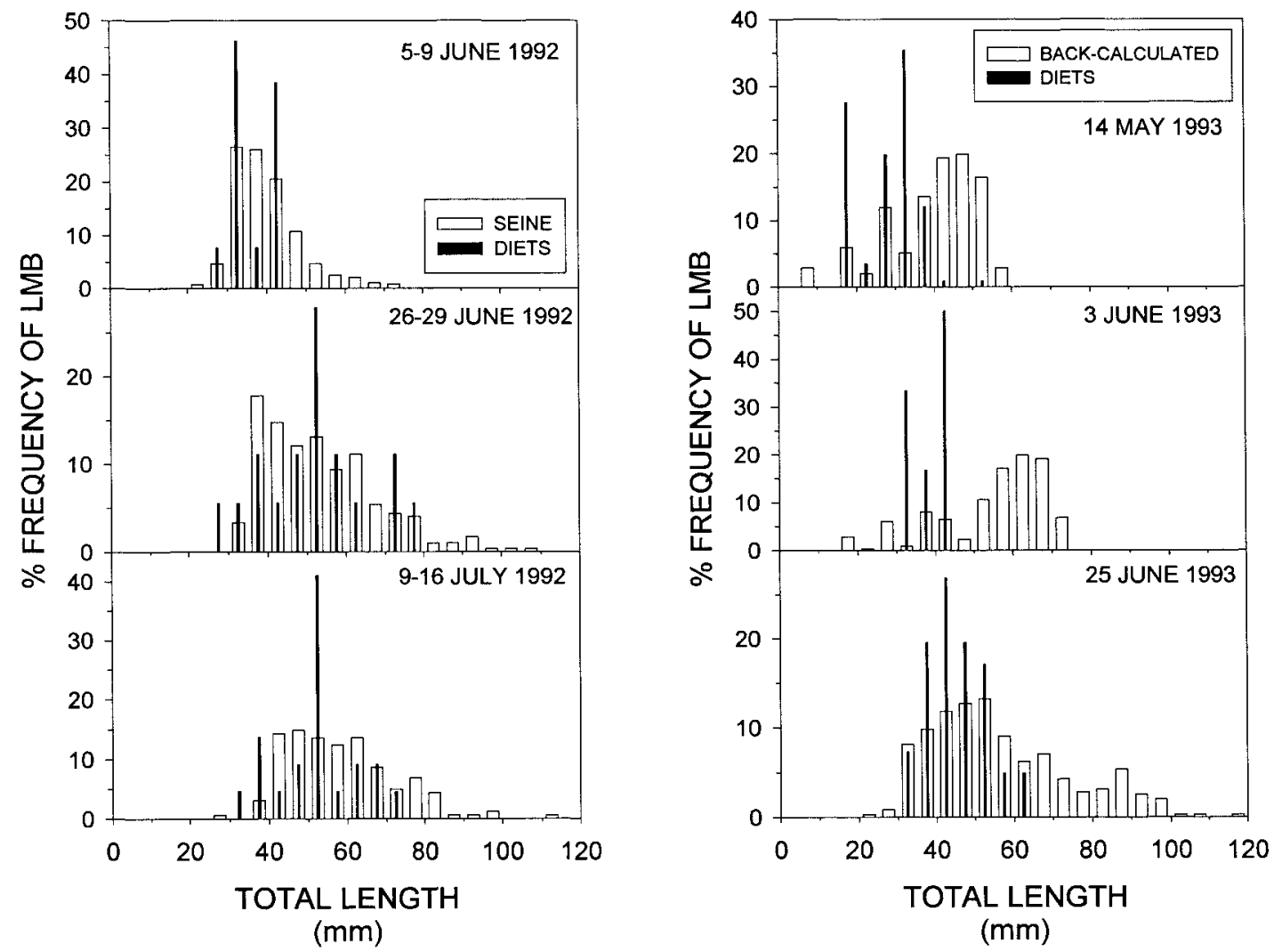

Figure 3.-Length-frequency distributions of young-of-year largemouth bass from diets of adult largemouth bass (black bars) and from seine collections (open bars). 

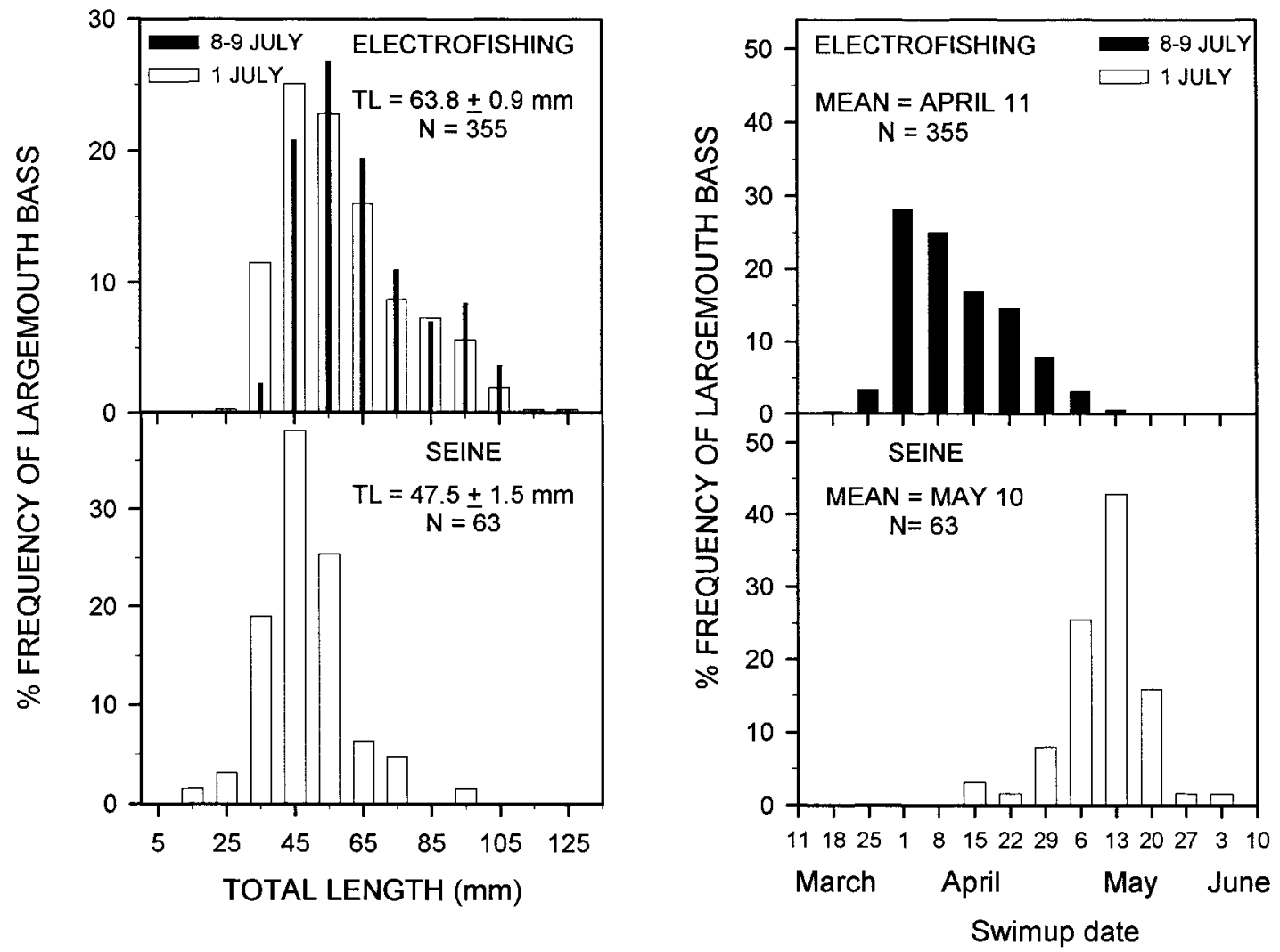

Figure 4.--Length-frequency distributions (left panels) and swim-up date distributions (right panels) of youngof-year largemouth bass collected via electrofishing (upper panels) and seining (lower panels). The narrow black bars in the upper left panel represent the actual lengths of fish on 8-9 July 1993, whereas the open bars are the lengths back-calculated to 1 July 1993 (generated using the average growth rate, as described in text) to allow for direct comparison between electrofishing and seining samples.

bass caught using seines relative to that seen in fish captured via electrofishing gear during summer in Ohio reservoirs (also see Reynolds 1996; Willis and Murphy 1996). Similarly, Jackson and Noble (1995) found that seining was less effective for sampling fish larger than $60 \mathrm{~mm}$ in TL (relative to sampling via a handheld electrofishing unit) and that a boat-mounted boom unit underestimated the abundance of fish smaller than $150 \mathrm{~mm}$. In order to assess the plausibility of gear avoidance as a mechanism for the missing early-hatched cohorts, we compared lengths and ages of seined youngof-year largemouth bass collected on 1 July 1993 to those of fish collected on 8-9 July with electrofishing. In order to control for the 7-8-d difference in collection dates, we used the average daily growth rate $(0.67 \mathrm{~mm} / \mathrm{d}$; see Methods $)$ to back-calculate the length that electrofished fish would have achieved on 1 July 1993. Seines clear- ly collected smaller fish than did electrofishing gear ( $Z$ test: $Z=4.38, P<0.0001$; Figure 4 ). Apparently seines did not capture fish larger than $80 \mathrm{~mm}$ TL as efficiently as did electrofishing gear (Figure 4, left panels), which helps explain why fish older than about $80 \mathrm{~d}$ (i.e., early-hatched cohorts) were missing from 1 July seine samples (Figure 4, right panels). Gear avoidance could also explain the early mean swim-up date for fish collected in early and late May relative to that of June/ July seine samples during 1992 (one-way ANOVA, Tukey's honestly significant difference: $F=$ $134, \mathrm{df}_{3,416}, P<0.001$; Figure 1$)$. It is likely that during May 1992, all young-of-year largemouth bass were vulnerable to the seine because they were less than $80 \mathrm{~mm}$ in TL (W. E. Pine, unpublished data). However, during June and July, we could not efficiently capture (i.e., in proportion to their abundance) the larger, early-hatched fish, 
which resulted in swim-up-frequency distributions that were skewed toward smaller, latehatched fish.

Age-dependent mortality operating during spring and summer has been shown to be important in understanding the recruitment dynamics of some fishes (Crecco and Savoy 1985; Rutherford and Houde 1995). Although we cannot say for certain whether age-dependent mortality occurred through the spring and summer in southern largemouth bass populations because of our gear avoidance problems, this does not appear to be the case. In this study, protracted spawning reduced the ability of seines to adequately sample all young-of-year largemouth bass; seines overrepresented the abundance of smaller, young individuals and underrepresented the larger, older individuals. The addition of electrofishing data in 1993 supports our conclusion that age-dependent mortality did not lead to differential cohort losses, although having these data for 1992 would certainly have strengthened our conclusions.

While we found that size-dependent cannibalism may reduce the survival of smaller, younger largemouth bass, its importance to understanding first-summer survival at the cohort level appears to be minimal in these systems, given that individuals from all cohorts (both early and late hatched) survived to July. This is not to say that size-dependent cannibalism cannot play a role in these systems, because we do not yet know how cumulative mortality operating at low levels during summer and fall can structure populations (Forney 1977; Houde 1987, 1989; Rice et al. 1993). As such, the survival bottleneck for these southern populations appears to occur during their first winter (Miranda and Hubbard 1994a, 1994b; Ludsin and DeVries 1997). The fact that recruitment appears to be set during juvenile stages rather than larval stages is consistent with other research into the freshwater recruitment process (Rothschild 1986; Houde 1987; Walters and Juanes 1993).

Indeed, explicit conclusions about early life survival remain difficult to make. Although agedependent mortality does not appear to occur at high levels during summer in these systems, we still suggest that events taking place during spring and summer can be important to understanding recruitment. First, we do not know the absolute levels of mortality occurring during these early life periods. A host of factors, including starvation and predation, can interact in a cumulative manner during this time to influence survival to later life stag- es and, ultimately, recruitment to the fishery (Houde 1987; Rice et al. 1987; Garvey et al. 1998). Second, many examples exist in which stochastic abiotic factors (e.g., low water temperature and water level fluctuations) have resulted in agedependent mortality, reduced year-class strength, and recruitment failure in fishes (Kramer and Smith 1962; Busch et al. 1975; Clady 1976; Rice et al. 1987; Freeberg et al. 1990; Reinert et al. 1997; Mion et al. 1998). Third, because early life events are interdependent (Ludsin and DeVries 1997), timing of spawning may be the single most important determinant of largemouth bass yearclass strength in southern systems. Clearly, earlyhatched fish have an advantage over late-hatched ones relative to their ability to forage on a wider (and likely energetically more beneficial) prey base, which ultimately results in enhanced lipid accumulation and increased survival over their first winter (Ludsin and DeVries 1997). Likewise, Cargnelli and Gross (1996) found that earlyhatched bluegill attained the largest body size and contributed $40 \%$ of the total recruits in Lake Opincion, Ontario, even though they accounted for only $17 \%$ of the total fry production. Conversely, Donovan et al. (1997) demonstrated that saugeye Stizostedion vitreum $\times S$. canadense stocked in early spring grew better but exhibited lower survival than did saugeye stocked later in spring. Finally, alternating life history strategies (Bayliss et al. 1993), in which late-spawned individuals produce early-hatched progeny, remain to be explored for southern largemouth bass populations.

\section{Conclusions}

With this work, we attempted to further our mechanistic understanding of largemouth bass recruitment, ultimately as a means to enhance our ability to manage largemouth bass populations. Although these results were produced in a relatively simplistic setting (i.e., in two-species pond systems), we suggest that our results may be applied to larger, more complex reservoirs and natural lakes. First, these results point to the importance of appropriately selecting sampling gear. We encourage researchers to use multiple gears, when possible, to sample individuals that may be separated temporally or spatially. Second, this work offers hypotheses concerning first-year survival that can be tested in larger, more complex systems. Because early-hatched largemouth bass cohorts appear to survive as well as (if not better than) late-hatched ones during summer and since larger individuals are the ones that likely recruit in south- 
ern systems, managers may want to consider harvest strategies that protect early spawners (Goodgame and Miranda 1993; Garvey and Stein 1998; Mion et al. 1998). Of course, there is no guarantee that early-hatched largemouth bass will survive well in a given year because of the stochastic nature of weather. However, because of the interdependency and predictive nature of early life events (Ludsin and DeVries 1997), shifting the average time of spawning in a population to an earlier date should increase the probability of producing strong year-classes over the long term by enhancing young-of-year growth during the summer and, ultimately, survival during the first winter.

\section{Acknowledgments}

We thank G. Kim, D. Partridge, J. Hoxmeier, J. Putman, B. Shaner, and V. Travnicek for their help in the field and laboratory and K. Tugend, M. Allen, the Aquatic Ecology Laboratory, and three anonymous reviewers for comments on previous drafts of this manuscript. This research was supported in part by National Science Foundation grants DEB-9108986 and DEB-9410323 and Federal Aid in Sport Fish Restoration project F40-R (administered by the Alabama Game and Fish Division to D. R. DeVries). This manuscript is publication 8-996054 of the Alabama Agricultural Experiment Station.

\section{References}

Bayliss, J. R., D. D. Wiegmann, and M. H. Hoff. 1993. Alternating life histories of smallmouth bass. Transactions of the American Fisheries Society 122:500_ 510.

Busch, W. D. N., R. L. School, and W. L. Hartman. 1975. Environmental factors affecting the strength of walleye (Stizostedion vitreum vitreum) year-classes in western Lake Erie. Journal of the Fisheries Research Board of Canada 32:1733-1743.

Cargnelli, L. M., and M. R. Gross. 1996. The temporal dimension in fish recruitment: birth date, body size, and size-dependent survival in a sunfish (bluegill: Lepomis macrochirus). Canadian Journal of Fisheries and Aquatic Sciences 53:360-367.

Clady, M. D. 1976. Influence of temperature and wind on the survival of early stages of yellow perch, Perca flavescens. Journal of the Fisheries Research Board of Canada 33:1887-1893.

Crecco, V. A., and T. F. Savoy. 1985. Effects of biotic and abiotic factors on growth and relative survival of young American shad, Alosa sapidissima, in the Connecticut River. Canadian Journal of Fisheries and Aquatic Sciences 42:1640-1648.

DeAngelis, D. L., D. K. Cox, and C. C. Coutant. 1980. Cannibalism and size dispersal in young-of-the-year largemouth bass: experiment and model. Ecological Modelling 8:133-148.

Donovan, N. S., R. A. Stein, and M. M. White. 1997. Enhancing percid stocking success by understanding age-0 piscivore-prey interactions in reservoirs. Ecological Applications 7:1311-1329.

Forney, J. L. 1977. Evidence of inter- and intraspecific competition as factors regulating walleye (Stizostedion vitreum vitreum) biomass in Oneida Lake, New York. Journal of the Fisheries Research Board of Canada 34:182-190.

Freeberg, M. H., W. W. Taylor, and R. W. Brown. 1990. Effect of egg and larval survival on year-class strength of Lake Whitefish in Grand Traverse Bay, Lake Michigan. Transactions of the Americans Fisheries Society 119:92-100.

Garvey, J. E., and R. A. Stein. 1998. Linking bluegill and gizzard shad prey assemblages to growth of age0 largemouth bass in reservoirs. Transactions of the American Fisheries Society 127:70-83.

Garvey, J. E., R. A. Wright, and R. A. Stein. 1998. Overwinter growth and survival of age-0 largemouth bass (Micropterus salmoides): revisiting the role of body size. Canadian Journal of Fisheries and Aquatic Sciences 55:2414-2424.

Goodgame, L. S., and L. E. Miranda. 1993. Early growth and survival of age-0 largemouth bass in relation to parental size and swim-up time. Transactions of the American Fisheries Society 122:131-138.

Hayes, D. B., C. P. Paola Ferreri, and W. W. Taylor. 1996. Active fish captive methods. Pages 193-218 in B. R. Murphy and D. W. Willis, editors. Fisheries techniques, 2nd edition. American Fisheries Society, Bethesda, Maryland.

Hjort, J. 1914. Fluctuations in the great fisheries of northern Europe viewed in the light of biological research. Rapports et Procès-Verbaux des Réunions Conseil International pour l'Exploration de la Mer 20:1-228.

Houde, E. D. 1987. Fish early life dynamics and recruitment variability. Pages $17-29$ in R. D. Hoyt, editor. 10th Annual larval fish conference. American Fisheries Society, Symposium 2, Bethesda, Maryland.

Houde, E. D. 1989. Subtleties and episodes in the early life of fishes. Fish Biology 35(Supplement A):29-38.

Houde, E. D. 1994. Differences between marine and freshwater fish larvae: implications for recruitment. ICES Journal of Marine Science 51:91-97.

Jackson, J. R., and R. N. Noble. 1995. Selectivity of sampling methods for juvenile largemouth bass in assessments of recruitment processes. North American Journal of Fisheries Management 15:408-418.

Keast, A., and J. M. Eadie. 1985. Growth depensation in year-0 largemouth bass: the influence of diet. Transactions of the American Fisheries Society 114: 204-213.

Kramer, R. H., and L. L. Smith. 1962. Formation of year classes in largemouth bass. Transactions of the American Fisheries Society 91:29-41.

Ludsin, S. A. 1994. Understanding first-year survival of a freshwater piscivore: the interdependency of 
life-history stages. Master's thesis. Auburn University, Auburn, Alabama.

Ludsin, S. A., and D. R. DeVries. 1997. First-year recruitment of largemouth bass: the inter-dependency of early life stages. Ecological Applications 7: $1024-1038$.

May, R. C. 1974. Larval mortality in marine fishes and the critical periods concept. Pages 3-19 in J. H. S. Blaxter, editor. The early life history of fish. Springer-Verlag, Berlin.

Mcdonough, T. A., and J. P. Buchanan. 1991. Factors affecting abundance of white crappies in Chickamauga reservoir, Tennessee, 1979-1989 North American Journal of Fisheries Management 11: 513-525.

Miller, S. J., and T. Storck. 1982. Daily growth rings in otoliths of young-of-the-year largemouth bass. Transactions of the American Fisheries Society 111: 527-530.

Miller, S. J., and T. Storck. 1984. Temporal spawning distribution of largemouth bass and young-of-year growth, determined from daily otolith rings. Transactions of the American Fisheries Society 113:571578.

Miller, T. L., L. B. Crowder, J. A. Rice, and E. A. Marschall. 1988. Larval size and recruitment mechanisms in fishes: toward a conceptual framework. Canadian Journal of Fisheries and Aquatic Sciences 45:1657-1670.

Mion, J. B., R. A. Stein, and E. A. Marschall. 1998. River discharge drives survival of larval walleye. Ecological Applications 8:88-104.

Miranda, L. E., and W. D. Hubbard. 1994a. Lengthdependent winter survival and lipid composition of age-0 largemouth bass in Bay Springs Reservoir, Mississippi. Transactions of the American Fisheries Society 123:80-87.

Miranda, L. E., and W. D. Hubbard. 1994b. Winter survival of age-0 largemouth bass relative to size, predators, and shelter. North American Journal of Fisheries Management 14:790-796.

Mitzner, L. 1991. Effect of environmental variables upon crappie young, year-class strength, and the sport fishery. North American Journal of Fisheries Management 11:534-543.

Mooij, W. M., E. H. R. R. Lammens, and W. L. T. VanDeasen. 1994. Growth rate of $0+$ fish in relation to temperature, body size, and food in shallow eutrophic Lake Tjeukemeer. Canadian Journal of Fisheries and Aquatic Sciences 51:516-526.

Phillips, J. M., J. R. Jackson, and R. L. Noble. 1995. Hatching date influence of age-specific diet and growth of age-0 largemouth bass. Transactions of the American Fisheries Society 124:370-379.

Post, J. R., and D. O. Evans. 1989. Experimental evidence of size-dependent mortality in juvenile yel- low perch. Canadian Journal of Zoology 67:521523.

Reinert, T. R., G. R. Ploskey, and M. J. Van Den Avyle. 1997. Effects of hydrology on black bass reproductive success in four southeastern reservoirs. Proceedings of the Annual Conference of the Southeastern Association of Fish and Wildlife Agencies 49:47-57.

Reynolds, J. B. 1996. Electrofishing. Pages 221-251 in B. R. Murphy and D. W. Willis, editors. Fisheries techniques, 2nd edition. American Fisheries Society, Bethesda, Maryland.

Rice, J. A., L. B. Crowder, and M. E. Holey. 1987. Exploration of mechanisms regulating larval survival in Lake Michigan bloater: a recruitment analysis based on characteristics of individual larvae. Transactions of the American Fisheries Society 116: 703-718.

Rice, J. A., T. J. Miller, K. A. Rose, L. B. Crowder, E. A. Marschall, A. S. Trebitz, and D. L. DeAngelis. 1993. Growth rate variation and larval survival: inferences from an individual-based size-dependent predation model. Canadian Journal of Fisheries and Aquatic Sciences 50:133-142.

Rothschild, B. J. 1986. Dynamics of marine fish populations. Harvard University Press, Cambridge, Massachusetts.

Rutherford, E. S., and E. D. Houde. 1995. The influence of temperature on cohort-specific growth, survival, and recruitment of striped bass, Morone saxatilus larvae in Chesapeake Bay. Fishery Bulletin 97:315332.

SAS Institute, Inc. 1985. SAS users guide: statistics, version 6. SAS Institute, Inc., Cary, North Carolina.

Swingle, H. S., and W. E. Swingle. 1967. Problems in dynamics of fish populations in reservoirs. Pages 29-243 in American Fisheries Society, Reservoir Committee, editor. Reservoir fishery resources symposium. American Fisheries Society, Southern Division, Reservoir Committee, Bethesda, Maryland.

Townsend, C. R. 1989. Population cycles in freshwater fish. Journal of Fish Biology 30(Supplement A): 125-131.

Van Den Avyle, M. J., and J. E. Roussel. 1980. Evaluation of a simple method for removing food items from live black bass. Progressive Fish-Culturist 42: 222-223.

Walters, C. J., and F. Juanes. 1993. Recruitment limitation as a consequence of natural selection for use of restricted feeding habitats and predation risk taking by juvenile fishes. Canadian Journal of Fisheries and Aquatic Sciences 50:2058-2070.

Willis, D. W., and B. R. Murphy. 1996. Planning for sampling. Pages $1-15$ in B. R. Murphy and D. W. Willis, editors. Fisheries techniques, 2nd edition. American Fisheries Society, Bethesda, Maryland.

Zar, J. H. 1984. Biostatistical analysis, 2nd edition. Prentice-Hall, Englewood Cliffs, New Jersey. 